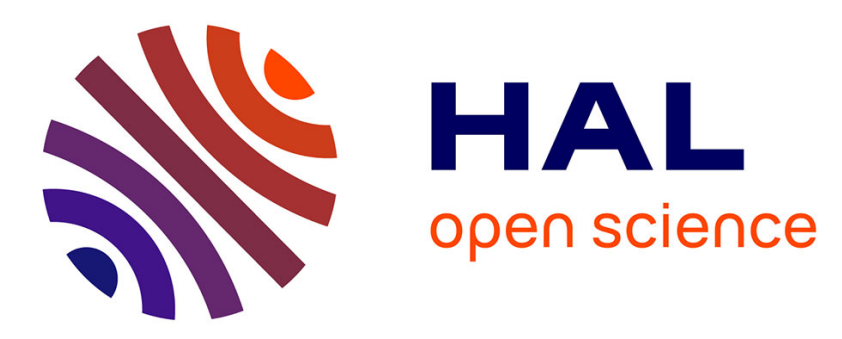

\title{
A terbium(III) luminescent ATCUN-based peptide sensor for selective and reversible detection of copper(II) in biological media
}

Enrico Falcone, Paulina Gonzalez, Lucie Lorusso, Olivier Sénèque, Peter Faller, Laurent Raibaut

\section{To cite this version:}

Enrico Falcone, Paulina Gonzalez, Lucie Lorusso, Olivier Sénèque, Peter Faller, et al.. A terbium(III) luminescent ATCUN-based peptide sensor for selective and reversible detection of copper(II) in biological media. Chemical Communications, 2020, 56 (35), pp.4797-4800. 10.1039/D0CC01007C . hal-02917280

\section{HAL Id: hal-02917280 \\ https://hal.science/hal-02917280}

Submitted on 18 Aug 2020

HAL is a multi-disciplinary open access archive for the deposit and dissemination of scientific research documents, whether they are published or not. The documents may come from teaching and research institutions in France or abroad, or from public or private research centers.
L'archive ouverte pluridisciplinaire HAL, est destinée au dépôt et à la diffusion de documents scientifiques de niveau recherche, publiés ou non, émanant des établissements d'enseignement et de recherche français ou étrangers, des laboratoires publics ou privés. 


\section{A Terbium(III) luminescent ATCUN-based peptide sensor for selective and reversible detection of Copper(II) in biological media.}

Enrico Falcone, ${ }^{a}$ Paulina Gonzalez, ${ }^{a}$ Lucie Lorusso, ${ }^{a}$ Olivier Sénèque, ${ }^{b}$ Peter Faller, ${ }^{* a}$ and Laurent Raibaut*a

The measurement of exchangeable $\mathrm{Cu}^{2+}$ levels in biological samples is gaining interest in the context of copper-related pathologies. Here, we report a $\mathrm{Tb}^{3+}$ luminescent turn-off sensor for $\mathrm{Cu}^{2+}$ based on the specific and suitable-affinity Xxx-Zzz-His (ATCUN) peptide motif, enabling $\mathrm{Cu}^{2+}$ detection in the presence of a biological fluorescent background.

Copper is a catalytic co-factor essential for most organisms to accomplish several biochemical tasks, such as cellular respiration, radicals scavenging and neurotransmitter synthesis. ${ }^{1}$ Notwithstanding, excess of loosely bound copper can be toxic as its redox cycling between $\mathrm{Cu}^{2+}$ and $\mathrm{Cu}^{+}$generates Reactive Oxygen Species (ROS). Therefore, copper is tightly coordinated, mainly as $\mathrm{Cu}^{2+}$, by a number of extracellular carriers (ceruloplasmin, serum albumin, $\alpha_{2}$-macroglobulin, small ligands), and mainly as $\mathrm{Cu}^{+}$by membrane transporters (Ctr1/2, ATP7A/B) and intracellular metallo-chaperones (Atox1, CCS, Cox17), which ensure proper copper homeostasis. ${ }^{2,3}$ However, this tight control is lost in genetic disorders such as Menkes' and Wilson's diseases and in amyloid diseases such as Alzheimer's and Parkinson's diseases. ${ }^{4,5}$ Interestingly, increased levels of serum and urine copper, especially those of the exchangeable (i.e. kinetically labile) copper pool, are gaining interest as potential new markers of these pathologies. ${ }^{6-9}$ Whilst the measurement of total copper levels by means of classical techniques (AAS, ICP-MS, ICP-AES) is well established, probes for the measurement of exchangeable $\mathrm{Cu}$ levels are still under development. ${ }^{10-13}$ In order to be competitive with $\mathrm{Cu}$ physiological partners, such a probe should have an affinity of the same order of magnitude. In particular, if the affinity of the probe for $\mathrm{Cu}$ is too high, it is always loaded and hence it cannot respond to fluctuations. Likewise, if the affinity is too low, the probe is always empty.

The Amino Terminal $\mathrm{Cu}^{2+}$ - and $\mathrm{Ni}^{2+}$-binding (ATCUN) $\mathrm{Xxx}$-Zzz-His motif, ${ }^{14}$ naturally found in proteins and peptides such as serum albumin, $^{15}$ hepcidin ${ }^{16}$ and Neuromedin C (NMC), ${ }^{17}$ has been exploited to develop $\mathrm{Cu}^{2+}$-selective sensors by its conjugation with common green-emitting dyes. ${ }^{18-23}$ The selectivity of such $4 \mathrm{~N}\left(\mathrm{NH}_{2}, 2 \times \mathrm{N}^{-}, \mathrm{N}_{\mathrm{Im}}\right)$ binding motif for $\mathrm{Cu}^{2+}$ stems from the strong Lewis acid character and the preference for square-planar coordination geometry. Interestingly, the suitable affinity of the ATCUN motif $\left(12<\log { }^{c} K_{7.4}<15\right.$, depending on the identity of $X x x, Z z z$ and the sequence after His) ${ }^{14}$ ensures competitiveness against the endogenous $\mathrm{Cu}^{2+}$ ligands. Indeed, Human Serum Albumin (HSA, $\left.\log { }^{c} K_{7.4} \approx 13\right)^{24}$ is only partially loaded with $\mathrm{Cu}$ under normal physiological conditions, indicating that it has the right affinity to detect fluctuations. The above-mentioned dyeATCUN sensors are reversible and based on fluorescence turnoff, as paramagnetic $\mathrm{Cu}^{2+}$ quenches fluorescence. ${ }^{25}$ Conversely, turn-on $\mathrm{Cu}^{2+}$-sensors reported are commonly not reversible, as they are based on a chemical reaction that yields a fluorescent product. $^{26,27}$ Indeed, we recently proved that at least one of several alleged turn-on binding-based probes works through irreversible $\mathrm{Cu}^{2+}$-induced sensor oxidation. ${ }^{28}$

On the other hand, fluorescent sensing in biological media is challenged by the intrinsic fluorescence background of biomolecules such as proteins and cofactors. This issue can be overcome, for instance, employing long-lifetime luminophores, which allow getting rid of the biological fluorescence background via time-delayed detection. In this respect, luminescent trivalent lanthanide ions $\left(\mathrm{Ln}^{3+}\right)$ have long-lifetime emission (in the millisecond range) and show very interesting photophysical properties, such as ligand-independent atom-like narrow emission bands, large Stokes shift and low tendency to photobleach. ${ }^{29}$ However, the lanthanide-based probes for $\mathrm{Cu}^{2+}$ that have hitherto been reported are based on ligands that do not benefit from the advantageous properties of the ATCUN motif, i.e. the high selectivity for $\mathrm{Cu}^{2+}$, the appropriate affinity and the reversibility. ${ }^{30-36}$ 


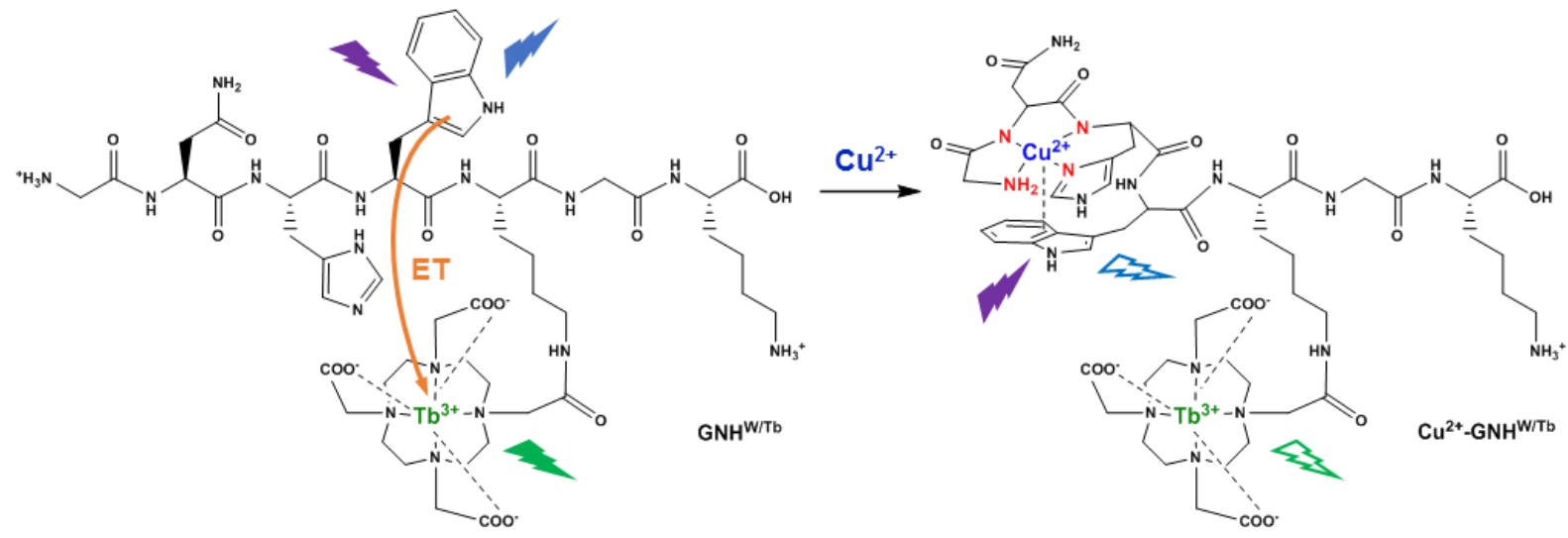

Figure 1. Structure and schematic mechanism of $\mathrm{Cu}^{2+}$ sensing by $\mathrm{GNH}^{\mathrm{w} / \mathrm{Tb}}$ : in absence of $\mathrm{Cu}^{2+}$, Trp excitation (violet flash) gives rise to $\mathrm{Trp}$ (blue flash) emission and also Tb ${ }^{3+}$ (green flash) emission via energy transfer (ET, orange arrow); upon $\mathrm{Cu}^{2+}$-binding to the peptide ATCUN motif, both Trp and Tb ${ }^{3+}$ luminescence is quenched.

In this article, we present the design of a turn-off luminescent peptide for $\mathrm{Cu}^{2+}$, combining the selectivity and suitable affinity of the ATCUN motif with the long-lifetime emission of the lanthanide $\mathrm{Tb}^{3+}$, and we prove its suitability for $\mathrm{Cu}^{2+}$ sensing in biological-like media via time-resolved luminescence detection. As the low extinction coefficients of the Laporte-forbidden $4 \mathrm{f}-4 \mathrm{f}$ transitions impair the efficient excitation of $\mathrm{Ln}^{3+}$ ions, it is necessary to resort to the so-called "antenna effect", i.e. the energy transfer from a suitable excited chromophore to the accepting excited electronic levels of $\mathrm{Ln}^{3+} .{ }^{37}$ Typically, the amino acid tryptophan ( $\operatorname{Trp}$ ) can be chosen as an antenna due to its recognised ability to sensitize $\mathrm{Tb}^{3+}$ ions and its straightforward inclusion into a peptide scaffold. ${ }^{38-41}$ Thus, we designed a Tb $^{3+}$ luminescent ATCUN peptide, GNHW/Tb (GNHWK ${ }^{\text {DOTA(Tb) }}$ GK-NH${ }_{2}$ ), containing the first four $\mathrm{N}$-terminal amino acids (GNHW) of the peptide NMC, which includes the ATCUN motif and a Tb ${ }^{3+}$-DOTA luminescent complex grafted on a lysine residue next to the Trp antenna (see Figure 1). GNHW/Tb was obtained using classical peptide synthesis methodology (see Figure S1 and S2).

First, the luminescent properties of $\mathbf{G N H}^{\mathbf{W} / \mathrm{Tb}}$ were investigated by steady-state luminescence spectroscopy in HEPES buffer $(\mathrm{pH}$ 7.4). In the absence of $\mathrm{Cu}^{2+}$, excitation of $\operatorname{Trp}$ at $280 \mathrm{~nm}$ promotes its emission at $348 \mathrm{~nm}$, and by the antenna effect the characteristic emission of $\mathrm{Tb}^{3+}$ at $487,544,585$ and $623 \mathrm{~nm}$ due to ${ }^{5} D_{4} \rightarrow{ }^{7} \mathrm{~F}_{\mathrm{J}}(\mathrm{J}=6,5,4,3)$ transitions. Indeed, time-delayed excitation spectrum (at $\lambda_{\mathrm{em}}=544 \mathrm{~nm}$ ), also confirmed that Trp acts as a sensitizing antenna for $\mathrm{Tb}^{3+}$ luminescence (Figure S3). Next, the effect of $\mathrm{Cu}^{2+}$ binding on the peptide luminescence was investigated by a $\mathrm{Cu}^{2+}$ titration (Figure $2 \mathrm{~A}$ ). $\mathrm{Cu}^{2+}$ addition caused the gradual quenching of both Trp and $\mathrm{Tb}^{3+}$ emission until one equivalent of $\mathrm{Cu}^{2+}$, confirming $1: 1 \mathrm{Cu}^{2+}: \mathrm{GNH}^{\mathrm{w} / \mathrm{Tb}}$ stoichiometric binding, as also shown by UV-vis titration via the increase of the $d-d$ band at $\lambda_{\max }=525 \mathrm{~nm}$ (Figure S4). Conversely, $\mathrm{Tb}^{3+}$ luminescence lifetime remained constant upon $\mathrm{Cu}^{2+}$ addition and equal to $\approx 1.97 \mathrm{~ms}$ (Figure S5) indicating that $\mathrm{Cu}^{2+}$ does not quench the $\mathrm{Tb}^{3+}$ excited state but quenches the Trp antenna $S_{1}$ excited state, resulting in lower efficiency of the antenna effect. Besides, the selectivity of the probe in the presence of a physiological concentration of other extracellular relevant di- and trivalent cations $\left(\mathrm{Zn}^{2+}, \mathrm{Fe}^{3+}, \mathrm{Co}^{2+}, \mathrm{Mn}^{2+} 10 \mu \mathrm{M}\right.$, $\mathrm{Mg}^{2+}$ and $\mathrm{Ca}^{2+} 2 \mathrm{mM}$ ) was evaluated. These cations did not alter significantly the intensity of Trp (Figure 2B) and $\mathrm{Tb}^{3+}$ emission bands (Figure S6), while $\mathrm{Cu}^{2+}$ did, even in the presence of all the other cations. Thus, $\mathbf{G N H}^{\mathbf{W} / \mathrm{Tb}}$ was able to detect specifically $\mathrm{Cu}^{2+}$ among these essential metals for humans, expected to be the main competitors in the extracellular space. Since the ATCUN motif also binds $\mathrm{Ni}^{2+}$ ions effectively, we investigated the effect of $\mathrm{Ni}^{2+}$ binding on $\mathbf{G N H}^{\mathrm{W} / \mathrm{Tb}}$ luminescence, which was efficiently quenched upon $\mathrm{Ni}^{2+}$ addition (Figure S7). Nevertheless, the sensor can be considered selective for $\mathrm{Cu}^{2+}$ since (i) $\mathrm{Ni}^{2+}$ is not a physiological ion for mammals, (ii) the affinity of the ATCUN motif for $\mathrm{Ni}^{2+}$ is about $5 \div 6$ orders of magnitude lower than for $\mathrm{Cu}^{2+}$ (for NMC, $\log { }^{c} K^{N i_{7.4}}=7.3$ and $\log { }^{c} K^{C u_{7.4}}=13.6$ ), and (iii) $\mathrm{Ni}^{2+}$-binding is much slower than $\mathrm{Cu}^{2+}$-binding. ${ }^{42,43}$

Next, we tested the ability of $\mathbf{G N H}^{\mathbf{W} / \mathrm{Tb}}$ in detecting $\mathrm{Cu}^{2+}$ in the presence of a more biologically relevant fluorescent background. In particular, we studied (i) the $\mathrm{Cu}^{2+}$ transfer from Pig Serum Albumin (PSA), which contain many fluorescent aromatic amino acids residues, to $\mathbf{G N H}^{\mathrm{w} / \mathrm{Tb}}$, and (ii) the $\mathrm{Cu}^{2+}$ sensing in a complex mixture such as Luria-Bertani (LB), which is rich in peptides and vitamins, including possible competing $\mathrm{Cu}^{2+}$-binding sites. In both cases, no significant change of the fluorescence emission intensity upon $\mathrm{Cu}^{2+}$ addition can be observed (Figures $3 \mathrm{~A}$ and S8A), as PSA or LB medium signal

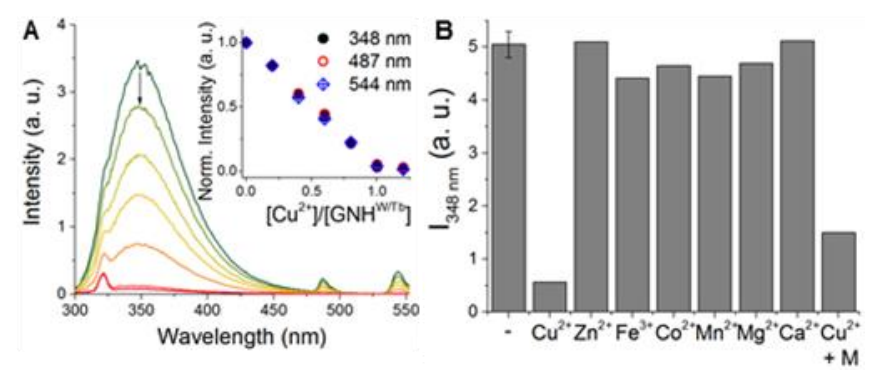

Figure 2. Selective $\mathrm{Cu}^{2+}$ sensing by $\mathrm{GNH}^{\mathrm{W} / \mathrm{Tb}}$ via $\mathrm{Trp}$ and $\mathrm{Tb}^{3+}$ luminescence quenching. (A) $\mathrm{Cu}^{2+}$ titration of the sensor. Conditions: [GNH'/Tb] $=10 \mu \mathrm{M}$, HEPES $100 \mathrm{mM}$ pH 7.4. (B) Effect of other physiologically relevant metal ions on Trp emission $(\mathrm{M}=$ mix of all the cations). Conditions: $\left[\mathrm{GNH}^{\mathrm{W} / \mathrm{Tb}}\right]=10 \mu \mathrm{M},\left[\mathrm{Cu}^{2+}\right]=\left[\mathrm{Zn}^{2+}\right]=\left[\mathrm{Fe}^{3+}\right]=\left[\mathrm{Co}^{2+}\right]=\left[\mathrm{Mn}^{2+}\right]=10 \mu \mathrm{M}$, $\left[\mathrm{Mg}^{2+}\right]=\left[\mathrm{Ca}^{2+}\right]=2 \mathrm{mM}$, HEPES $100 \mathrm{mM}, \mathrm{pH} 7.4$ 


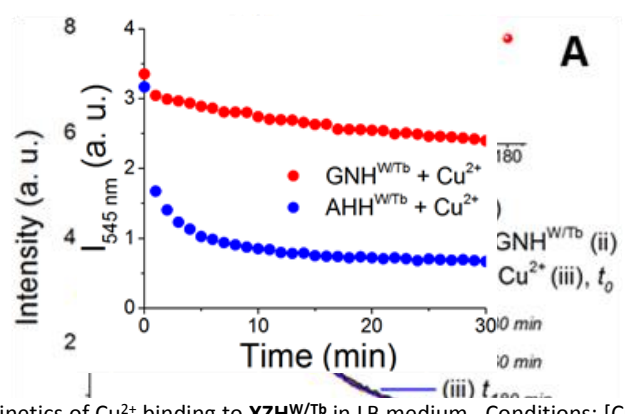

Figure 4. Kinetics of $\mathrm{Cu}^{2+}$ binding to $\mathrm{XZH}^{\mathrm{W} / \mathrm{Tb}}$ in $\mathrm{LB}$ medium. Conditions: $\left[\mathrm{Cu}^{2+}\right]=9 \mu \mathrm{M}$, $\left[\mathrm{XZH}^{\mathrm{W} / \mathrm{Tb}}\right]=10 \mu \mathrm{M}, \mathrm{LB}$ medium $10 \%$.

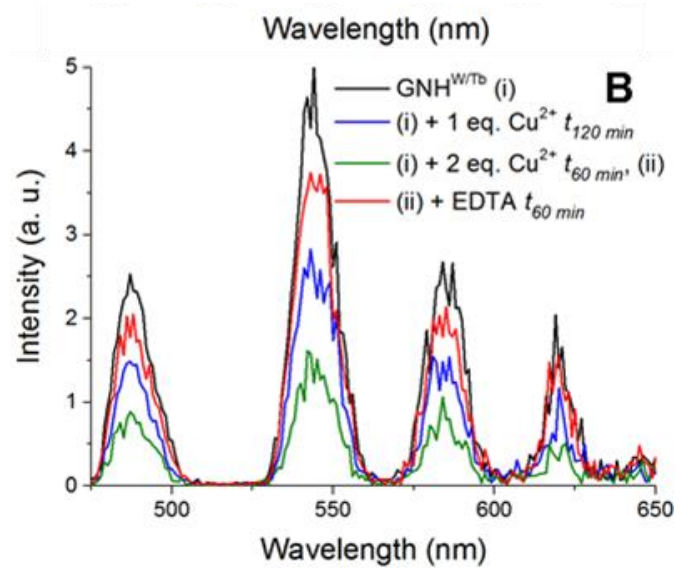

Figure 3. Reversible $\mathrm{Cu}^{2+}$ sensing by $\mathrm{GNH}^{\mathrm{w} / \mathrm{Tb}}$ in the presence of $\mathrm{LB}$ medium monitored by steady-state (A) and time-delayed (B) luminescence. Conditions: $\left[\mathrm{GNH}^{\mathrm{w} / \mathrm{Tb}}\right]=10 \mu \mathrm{M}$, [EDTA] $=100 \mu \mathrm{M}, \mathrm{LB} 10 \%$. Inset: kinetics profile of $\mathrm{Cu}^{2+}$ binding.

overrode that of the probe. Moreover, under steady-state fluorescence condition, the fluorescent background at higher wavelength was so intense that $\mathrm{Tb}^{3+}$ emission bands were undetectable in the presence of PSA or LB medium. Advantageously, long luminescence lifetime of $\mathrm{Tb}^{3+}$ allows to perform time-resolved detection and hence to get rid of the autofluorescence of the biological background. Under this condition, with a $100 \mu$ s time delay before the recording of the emission, only the emission bands of $\mathrm{Tb}^{3+}$ were observed (Figures 3B and S8B). As $\mathrm{Cu}^{2+}$ was slowly transferred from PSA to $\mathbf{G N H}^{\mathrm{W} / \mathrm{Tb}}$, the intensity of these bands progressively decreased (Figure S8B). To assess the reversibility of the sensor, an excess of the stronger $\mathrm{Cu}^{2+}$ chelator EDTA was added. The latter took $\mathrm{Cu}^{2+}$ slowly out from the sensor, restoring the initial signal. Time-delayed detection also allowed the measurement of $\mathrm{Tb}^{3+}$ emission in LB medium (Figure 3B). Specifically, the sensor showed a slow response and the quenching by $\mathrm{Cu}^{2+}$ was not complete, even upon the addition of an excess. Finally, the signal was slowly recovered by the addition of excess EDTA. This behaviour suggests that the sensor is likely in kinetic competition with $\mathrm{Cu}^{2+}$-binding medium components. Indeed, $\mathrm{Cu}^{2+}$-binding to ATCUN motif is known to be slower than the binding to non-amide ligands, as amide deprotonation is relatively slow. ${ }^{44,45}$ Therefore, $\mathrm{Cu}^{2+}$ could bind first to kineticallyfavoured ligands in the medium and then move to the thermodynamically competitive ATCUN motif in the sensor. Overall, the observed behaviour shows that the designed sensor is sensitive to fluctuations of exchangeable $\mathrm{Cu}^{2+}$ levels in the presence of fluorescent background and possible competitors. In order to enhance the kinetic competitiveness of the sensor, we designed a sequence variant, $\mathbf{A H H}^{\mathrm{W} / \mathrm{Tb}}$ (AHHWK ${ }^{\mathrm{DOTA}}$ (Tb) GK$\mathrm{NH}_{2}$ ), bearing the ATCUN-like motif $X x x$-His-His, which occurs for instance in rice albumin $(D H H)^{46}$ and $A \beta_{12-x}$ fragment peptides $(\mathrm{VHH})$. The $\mathrm{AHH}$ motif has been recently investigated thoroughly. ${ }^{48,49}$ At $\mathrm{pH} 7.4 \mathrm{Cu}+$ binds predominantly in the ATCUN $4 \mathrm{~N}$ coordination mode, but a small portion is bound in a $3 \mathrm{~N}\left(\mathrm{NH}_{2}, \mathrm{~N}^{-}, \mathrm{N}_{\mathrm{Im}}\right)$ mode with an external ligand (Figure S9). $\mathrm{Cu}^{2+}$ exchanged much more rapidly in $\mathrm{AHH}$ than $\mathrm{AAH}$, which was attributed to the possible formation of ternary complexes of the $3 \mathrm{~N}$ form. In addition, $\mathrm{AHH}$ motif also shows higher affinity $\left(\log { }^{c} K_{7.4}=14.3\right)$ than $\mathrm{GNH}$. Hence, we first investigated $\mathrm{Cu}^{2+}$ $\mathbf{A H H}^{\mathrm{W} / \mathrm{Tb}}$ interaction by UV-vis and luminescence titrations (Figures S10), which showed similar behaviour to $\mathbf{G N H}^{\mathbf{W} / \mathrm{Tb}}$. Then, we tested the kinetic properties of the probes, first comparing the rate of $\mathrm{Cu}^{2+}$ transfer from the simple dipeptide $\mathrm{AH}$ to the two sensors (Figure S11). Indeed, the $\mathbf{A H} \mathbf{H}^{\mathbf{W} / \mathrm{Tb}}$ revealed to be faster than the canonical GNHW/Tb.

Thus, we further compared the $\mathrm{Cu}^{2+}$-binding kinetics of the two sensors in the complex LB medium. The peptide $\mathbf{A H H}^{\mathrm{W} / \mathrm{Tb}}$ showed again faster $\mathrm{Cu}^{2+}$-binding than the $\mathrm{GNH}^{\mathrm{W} / \mathrm{Tb}}$, proving to be more readily responsive to $\mathrm{Cu}^{2+}$ levels fluctuation (Figure 4). In conclusion, in this work, we report for the first time a $\mathrm{Tb}^{3+}$ luminescent sensor for $\mathrm{Cu}^{2+}$ based on a naturally occurring ATCUN motif, proving its suitability for competing with endogenous ligand and for applications in biological media. This represents a proof of principle study showing the favourable application of $\mathrm{Ln}^{3+}$-based ATCUN-bearing peptide probes to study $\mathrm{Cu}^{2+}$ handling. Advantageously, the versatility of this peptide scaffold opens the way for improving and tuning sensitivity, affinity and kinetics of this prototype by modulating the amino acid sequence as well as the nature of the antenna$\mathrm{Ln}^{3+}$ couple. Such optimised sensors could not only be applied to monitor $\mathrm{Cu}^{2+}$ transfer reactions in vitro but have also the potential to be used in cell cultures and biological fluids.

We acknowledge Dr Gilles Ulrich (UMR 7515, Strasbourg) for help with lifetime measurements, Dr Loïc Charbonnière and $\mathrm{Dr}$ Clémence Cheignon (UMR 7178, Strasbourg) for help with timedelayed luminescence measurements, and Dr Elise Glattard (UMR 7177, Strasbourg) for LB medium preparation. We acknowledge financial support from the French National Research Agency (ANR) through the Programme d'Investissement d'Avenir under contract 17-EURE-0016.

\section{Conflicts of interest}

There are no conflicts to declare.

\section{Notes and references}

R. A. Festa and D. J. Thiele, Curr. Biol., 2011, 21.

M. C. Linder, Metallomics, 2016, 8, 887-905.

N. J. Robinson and D. R. Winge, Annu. Rev. Biochem., 2010, 79, 537-562.

4 O. Bandmann, K. H. Weiss and S. G. Kaler, Lancet Neurol., 2015, 14, 103-113.

5 S. L. Sensi, A. Granzotto, M. Siotto and R. Squitti, Trends Pharmacol. Sci., 2018, 39, 1049-1063.

6 R. Squitti, R. Ghidoni, M. Siotto, M. Ventriglia, L. Benussi, A. 
Paterlini, M. Magri, G. Binetti, E. Cassetta, D. Caprara, F. Vernieri, P. M. Rossini and P. Pasqualetti, Ann. Neurol., 2014, 75, 574-580. R. Squitti, M. Siotto, M. Arciello and L. Rossi, Metallomics, 2016, 8, 863-873.

R. Squitti, R. Ghidoni, I. Simonelli, I. D. Ivanova, N. A. Colabufo, M. Zuin, L. Benussi, G. Binetti, E. Cassetta, M. Rongioletti and M. Siotto, J. Trace Elem. Med. Biol., 2018, 45, 181-188. M. Siotto and R. Squitti, Coord. Chem. Rev., 2018, 371, 8695.

G. A. McMillin, J. J. Travis and J. W. Hunt, Am. J. Clin. Pathol., 2009, 131, 160-165. S. El Balkhi, J. Poupon, J. M. Trocello, A. Leyendecker, F. Massicot, M. Galliot-Guilley and F. Woimant, Anal. Bioanal. Chem., 2009, 394, 1477-1484. S. Saito, M. Kawashima, H. Ohshima, K. Enomoto, M. Sato, H. Yoshimura, K. Yoshimoto, M. Maeda and M. Shibukawa, Analyst, 2013, 138, 6097-6105.

R. Squitti, M. Siotto, E. Cassetta, I. G. El Idrissi and N. A Colabufo, Clin. Chem. Lab. Med., 2017, 55, 1360-1367. P. Gonzalez, K. Bossak, E. Stefaniak, C. Hureau, L. Raibaut, W. Bal and P. Faller, Chem. - A Eur. J., 2018, 24, 8029-8041. W. Bal, J. Christodoulou, P. J. Sadler and A. Tucker, J. Inorg. Biochem., 1998, 70, 33-39.

D. Płonka and W. Bal, Inorganica Chim. Acta, 2018, 472, 76-81.

C. Harford and B. Sarkar, Biochem. Biophys. Res. Commun., 1995, 209, 877-882.

A. Torrado, G. K. Walkup and B. Imperiali, J. Am. Chem. Soc., 1998, 120, 609-610.

Y. Zheng, K. M. Gattás-Asfura, V. Konka and R. M. Leblanc, Chem. Commun., 2002, 2, 2350-2351.

C. Wende and N. Kulak, Chem. Commun., 2015, 51, 1239512398.

K. H. Jung and K. H. Lee, Anal. Chem., 2015, 87, 9308-9314. Y. Hao, W. Chen, L. Wang, X. Zhu, Y. Zhang, P. Qu, L. Liu, B. Zhou, Y. N. Liu and M. Xu, Talanta, 2015, 143, 307-314. A. Grüter, M. Hoffmann, R. Müller, T. Wohland and G. Jung, Anal. Bioanal. Chem., 2019, 411, 3229-3240.

K. Bossak-Ahmad, T. Frączyk, W. Bal and S. C. Drew, ChemBioChem, DOI:10.1002/cbic.201900435.

W. Yang, X. Chen, H. Su, W. Fang and Y. Zhang, Chem. Commun., 2015, 51, 9616-9619.

L. M. Hyman and K. J. Franz, Coord. Chem. Rev., 2012, 256, 2333-2356.

M. Saleem, M. Rafiq, M. Hanif, M. A. Shaheen and S. Y. Seo, J. Fluoresc., 2018, 28, 97-165.

E. Falcone, A. Sour, V. Lebrun, G. Ulrich, L. Raibaut and P. Faller, Dalt. Trans., 2019, 48, 14233-14237.

J. R. Lakowicz, Principles of fluorescence spectroscopy, 2006.

A. M. Nonat, A. J. Harte, K. Sénéchal-David, J. P. Leonard and T. Gunnlaugsson, J. Chem. Soc. Dalt. Trans., 2009, 4703-4711.

B. K. McMahon and T. Gunnlaugsson, Tetrahedron Lett., 2010, 51, 5406-5410.
Z. Liang, T. H. Tsoi, C. F. Chan, L. Dai, Y. Wu, G. Du, L. Zhu, C. S. Lee, W. T. Wong, G. L. Law and K. L. Wong, Chem. Sci., 2016, 7, 2151-2156.

Y. W. Yip, G. L. Law and W. T. Wong, Dalt. Trans., 2016, 45, 928-935.

Y. Wang, H. Wang, X. Zhao, Y. Jin, H. Xiong, J. Yuan and J. Wu, New J. Chem., 2017, 41, 5981-5987.

M. L. Aulsebrook, S. Biswas, F. M. Leaver, M. R. Grace, B. Graham, A. M. Barrios and K. L. Tuck, Chem. Commun., 2017, 53, 4911-4914.

M. Clerc, F. Heinemann, B. Spingler and G. Gasser, Inorg. Chem., 2020, 59, 669-677.

N. Sabbatini, M. Guardigli and J. M. Lehn, Coord. Chem. Rev., 1993, 123, 201-228.

J. P. MacManus, C. W. Hogue, B. J. Marsden, M. Sikorska and A. G. Szabo, J. Biol. Chem., 1990, 265, 10358-10366. I. D. Clark, I. Hill, M. Sikorska-Walker, J. P. MacManus and A. G. Szabo, FEBS Lett., 1993, 333, 96-98.

M. Isaac, L. Raibaut, C. Cepeda, A. Roux, D. Boturyn, S. V. Eliseeva, S. Petoud and O. Sénèque, Chem. - A Eur. J., 2017, 23, 10992-10996.

M. Isaac, A. Pallier, F. Szeremeta, P. A. Bayle, L. Barantin, C. S. Bonnet and O. Sénèque, Chem. Commun., 2018, 54, 7350-7353.

M. Sokolowska, A. Krezel, M. Dyba, Z. Szewczuk and W. Bal, Eur. J. Biochem., 2002, 269, 1323-1331.

A. B. Uceda, L. Mariño, M. Adrover and B. Vilanova, Inorganica Chim. Acta, , DOI:10.1016/j.ica.2019.119197. L. F. Wong, J. C. Cooper and D. W. Margerum, J. Am. Chem. Soc., 1976, 98, 7268-7274.

C. Hureau, H. Eury, R. Guillot, C. Bijani, S. Sayen, P.-L. Solari, E. Guillon, P. Faller and P. Dorlet, Chem. - A Eur. J., 2011, 17, 10151-10160.

C. Wei, D. N. Su, R. K. Mee and D. E. Sok, J. Agric. Food Chem., 2007, 55, 2149-2154. K. Bossak-Ahmad, M. Mital, D. Plonka, S. C. Drew and W. Bal, Inorg. Chem., 2019, 58, 932-943. P. Gonzalez, B. Vileno, K. Bossak, Y. El Khoury, P. Hellwig, W. Bal, C. Hureau and P. Faller, Inorg. Chem., 2017, 56, 14870-14879.

P. Gonzalez, K. Bossak-Ahmad, B. Vileno, N. E. Wezynfeld, Y. El Khoury, P. Hellwig, C. Hureau, W. Bal and P. Faller, Chem. Commun., 2019, 55, 8110-8113. 